De Nordiske Kriminalistforeninger 2009

\title{
De Nordiske KriminalistForeninger 2009
}

\section{Dansk Kriminalistforening}

Foreningens formand er direktør William Rentzmann. Sekretær og kasserer er advokat Bjørn Høberg-Petersen. Bestyrelsen bestod i 2009 endvidere af professor Flemming Balvig, dommer Peter Garde, professor Vagn Greve, politimester Lars Rand Jensen, overlæge Peter Kramp, forskningschef Britta Kyvsgaard, departementschef Michael Lunn, professor Gorm Toftegaard Nielsen, rigsadvokat Jørgen Steen Sørensen, højesteretsdommer Poul Dahl Jensen, arrestinspektør Jens Tolstrup og fuldmægtig Susanne Clausen.

Årsmødet i foreningen fandt sted den 9. februar 2010. Professor Vagn Greve var en af bestyrelsens tre medlemmer, der faldt for aldersgrænsen på 70 år, og måtte derfor udtræde af bestyrelsen. Han blev ved årsmødet udnævnt som foreningen tredje æresmedlem siden 1899. Efter generalforsamlingen holdt rigspolitichef Jens Henrik Højbjerg oplæg om 'Politireformen - status og perspektiver'.

Dansk Kriminologisk Selskab, der er et datterselskab til Dansk Kriminalistforening, arrangerede fem møder i 2009. Den 23. januar afholdt selskabet en paneldebat mellem redaktionschef Jens Grund, politiadvokat Jens Rasmussen og universitetslektor Jens Elo Rytter om "Journalister og straffelovgivningen". Debatten blev styret af professor Gorm Toftegaard-Nielsen. Den 10. juni indledte formanden for udvalget om "Endringer i politiklagesystemet", landsdommer Svend Bjerg Hansen og formanden for Dansk politiforbund Peter Ibsen om "Det nye politiklagesystem". Den 20. oktober indledte politidirektør Johan Reimann om "Regeringens ungdomskommission - hvad skal vi stille op med ungdomskriminaliteten?". Den 24. november indledte professor Peter Blume om "TV-overvågning af boligområder". Og den 7. december indledte professor Gorm Toftegaard-Nielsen om "Minimumsstraffe i Norden - hvordan påvirker Folketinget straffastscettelsen?".

Dansk Selskab for International Strafferet og EU-ret, der også er et datterselskab til Dansk Kriminalistforening, har i 2009 holdt ét møde. Det blev afholdt den 9. december, hvor vicestatsadvokat Lars Plum fra Statsadvokaten for Særlige Internationale Straffesager indledte om "Udlevering eller retsforfølgning i Danmark?"

Bestyrelsens hovedopgave i 2009 har været at planlægge det 15. Nordiske Kriminalistmøde i København, som finder sted d.19. til 21. august 2010.

Ved årets udgang havde Dansk Kriminalistforening 325 medlemmer. 


\section{Kriminalistföreningen i Sverige}

Vid årsmötet den 12 maj 2009 omvaldes styrelseledamöterna Jan Andersson, Sten Heckscher, Tomas Rothpfeffer, Fredrik Wersäll, Agneta Bäcklund, Magnus Ulväng, Peter Lindström, Owe Horned, Gudrun Antemar och Mattias Larsson. Till nya styrelseledamöter valdes rikspolischefen Bengt Svenson och docenten Eva Tiby. Lotta Gustavson och Annika Lowén omvaldes som revisorer. Patrik Örnsved omvaldes som revisorssuppleant.

Styrelsen har under året sammanträtt tre gånger.

Vid årsmötet utbytte professorn i kriminologi Jerzy Sarnecki och avdelningschefen vid Rikspolisstyrelsen Ulrika Herbst åsikter i ämnet "Har polisen noll koll?" Ämnet på vårpuben var "Brottsoffrens roll i domstolsförhandlingen". Medverkade gjorde advokaten Elisabeth Massi Fritz och professor Per Ole Träskman. På höstpuben berättade generaldirektören för Kriminalvården Lars Nylén om sin syn på framtidens kriminalvård.

Föreningen hade den 31 december 2009302 medlemmar.

\section{Kriminalistforeningen i Island}

Professor Ragnheiður Bragadóttir, det juridiske fakultet, Islands universitet, er ny formand for den Islandske Kriminalistforening.

Foreningens formand oplyser, at dr. jur. Ármann Snævarr, professor ved det juridiske fakultet 1948-1972, fhv. rektor ved Islands universitet og højesteretsdommer afgik ved døden den 15. februar 2010, 90 år gammel. Han var en af de vigtigste forskere i islandsk jura og hans værker handler om almen retslære, familieret, arveret og strafferet. Han var overordentlig aktiv i det nordiske samarbejde inden for sit fag. Sidste efterår blev der stiftet et institut om familieret i hans navn (Stofnun Ármanns Snævarr um fjölskyldumálefni) ved det juridiske fakultet, Islands universitet.

Ved årets udgang var der 7 medlemmer i den islandske kriminalistforening.

\section{Kriminalistföreningen i Finland - Suomen Kriminalistiyhdistys}

Föreningens styrelse har under redogörelseåret haft följande sammansättning; ordförande: professor Kimmo Nuotio, viceordförande: generaldirektör Esa Vesterbacka, sekreterare: jur. kand. Dan Helenius, kassör: jur. kand. Mikko Virkamäki. Styrelsens övriga medlemmar bestod av följande personer: överläkare Aulikki Ahlgren, vicechef Sanna Heikinheimo, domare vid Europeiska människorättsdomstolen Päivi Hirvelä, professor (tf.) Sakari Melander, överdirektör Maija Kukkonen, överlärare Matti Laine, institutionschef Tapio Lappi-Seppälä, justitieråd Liisa Mansikkamäki, hovrättsråd Tuomas Nurmi, advokat Jouko Pelkonen, justitieråd Pekka Koponen, konsultativ tjänsteman Tapio Sarvanti, generalsekreterare 
Hannu Takala och lagstiftningsdirektör Asko Välimaa. Styrelsen sammanträdde två gånger år 2009; den 15 januari och den 4 november. Jur.kand. Emilia Kaikkonen har även varit studentmedlem i styrelsen.

Professor Inkeri Anttila är hedersmedlem i föreningen.

Föreningens årsmöte hölls den 4 maj 2009.

Föreningens höstmöte hölls den 9 november 2009 i Justitieministeriets konferensutrymmen. Temat var "Lagberedningen på straffrättens område". Lagstiftningsdirektör Asko Välimaa och specialsakkunnig Matti Marttunen berättade om lagberedningen på straffrättens område inom justitieministeriets lagberedningsavdelning. Överdirektör Tapio Lappi-Seppälä och prof. (tf.) Sakari Melander gjorde särskilda inlägg på föreningens vägnar.

Vid årets slut hade föreningen 264 medlemmar.

\section{Norsk Kriminalistforening}

Leder er lagdommer Anne-Mette Dyrnes, Borgarting lagmannsrett. Styret har i 2009 ellers bestått av følgende personer: juridisk rådgiver ved Spesialenheten for politisaker Guro Kleppe (nestleder), professor Asbjørn Strandbakken, Universitetet i Bergen,direktør i Domstoladministrasjonen Tor Langbach, daglig leder i borgerrettsstiftelsen Stopp diskrimineringen, Berit Vegheim, advokatfullmektig Eldbjørg Håkonsen Martinsen (varamedlem) og.og forsker ved Institutt for kriminologi og rettssosiologi Jane Dullum. Foreningens sekretærer var førstekonsulent Knut-Fredrik Hustad og advokatfullmektig Gemetchu Hika frem til sommeren, mens stipendiat Synnøve Ugelvik overtok vervet alene fra august 2009.

Foreningen har i løpet året arrangert tre debattmøter. Etter årsmøtet 11. mars 2009 var det debattmøte om "Er juryordningens dager talte igjen?" Møtet ble arrangert i samarbeid med Advokatforeningen, Forsvarergruppen av 1977 og Institutt for kriminologi og rettssosiologi. Innledere var direktør Tor Langbach, advokat Trygve Staff, lagdommer Anders Bøhn og stipendiat Anders Løvlie.

Den 4. november 2009 arrangerte foreningen møte om temaet: "Den nye sexkjøpslovgivningen - hvordan virker den?" Innledere var Rune Swahn fra STOPgruppa ved Oslo politidistrikt, samt May-Len Skilbrei, forsker ved FAFO.

Den 2. desember 2009 ble det avholdt debattmøte om temaet "Nulltoleranse som politistrategi", med innledninger av Gro Smedsrud, stasjonssjef ved Manglerud politistasjon, og Nicolay B. Johansen, forsker ved Institutt for kriminologi og rettssosiologi, $\mathrm{UiO}$.

Det ble holdt tre styremøter i 2009.

Ved årsskiftet 2009/2010 var det registrert ca. 200 medlemmer. 